\title{
The effect of spraying of wheat straw extracts on controlling some weed species.
}

\author{
Kawa A. Ali ${ }^{1}$, Muhsin M. Qadir ${ }^{2}$, Samira O. Rasool ${ }^{3}$, Othman M. Hamad \\ ${ }^{1}$ (Field Crops, Agricultural College/ Salahaddin University, Iraq) \\ ${ }^{2,3,4}$ (Agricultural Research Center/Erbil-Iraq)
}

\begin{abstract}
This experiment was designed to compare the effect of spraying wheat straw aqueous extracts to control broad and narrow leaf weed plants in wheat fields with some common used herbicides in the region. The study consisted of five treatments; wheat straw aqueous extract; grass weeds herbicide clodinafop-propargyl (Topik); broad leaf herbicide tribenuron-methyl (Granstar); zero control (no weed control) and zero or noweed treatments, chlorophyll $a, b$ and total chlorophyll were indicated for all treatments after 48 hours from herbicide application. Results illustrated significant differences between all treatments, minimum wheat yield was recorded in zero control plots then plots that was treated with wheat straw aqueous extracts, Broad leaf weed herbicide (Granstar), narrow leaf weeds herbicide (Topic) and maximum yield was recorded with zero weed treatments, results of this study elucidate the potentiality of using wheat aqueous extracts for controlling some weed plants due to its obvious effect on reducing the weed plants height and the levels of chlorophyll $a, b$ and total chlorophyll in treated wheat plants.
\end{abstract}

Keywords - Allelopathy, Dicot, Monocot, weed plants.

\section{Introduction}

Wheat is the main field crop in Iraqi Kurdistan rain-fed area (Ismail, 2006) and (Marof 2007) despite the huge fluctuation in the annual rain fall the yield losses due to weed plants has been estimated to be $45 \%$ (Al-ali, 1982), so weed plants are the main obstacle that causes economic losses during agricultural season, while the major weed plants in the area could be classified as monocots or narrow leaf weeds such as; wild oat Avena fatua; canary grass Phalaris minor; rigid rye grass Lolium rigidum; rye grass Lolium temulentum; and dicots or broad leaf weeds such as wild mustard Brassica nigra, Cow cockle Vaccaria pyramidata, and syrian chephalaria Cephalaria syriaca (Hassawy et al., 1968) (Robson et al.,1991). Weed problems all over the world are getting worse due to the technological, economic and political factors (Gooding et al,. 1997) farmers in Iraqi Kurdistan as other farmers elsewhere prefer to use herbicides to control problematic weeds regardless to any environmental sequences. Dramatically beside the immoral herbicide use that causes serious damages on the agro-environment such as increasing herbicide resistance in weed plants, soil and irrigation water contamination, such misuse of chemical herbicides eventually causes killing of non-target organisms which might alter the natural balance of the area (Labrada et al., 1994). Utilizing the allelopathical potential in agricultural management systems may reduce the use of herbicides and minimize the pollution rates due to allelopathic active compounds that may provide novel chemistry for the synthesis of herbicides, insecticides, nematicides, and fungicides, hence allelopathy offers a new approach for the discovery of new leading compounds that might be used in an environmental friendly manner (Macias et al., 1999) and (Macias et al ., 2000). Crop or weed plants different parts, which possesses allelopathic potent might be selected for different uses as herbicid alternatives (Bhatti et al., 2000), (Brikett et al., 2001) and (Cheema and A. Khaliq, 2005). While comparing the efficiency of different used herbicides gives us acceptable indicator that investigators could depend on in future researches in the area of using plants extracts that could be environmentally safe (Ali, 2010). This investigation aim was to compare the wheat straw aqueous extracts spray effect with two widely used herbicides which were (Clodinafop-propargyl) Topik ${ }^{\circledR}$ and (Tribenuron-methyl) Granstar ${ }^{\circledR}$ in order to indicate the probability of utilizing the straw extracts as a bioherbicde in the region which may be easy and cheap solution for farmers.

\section{Material and methods}

A completely randomized block design experiment was established to investigate the effect of wheat straw aqueous extracts foliar application on growth and yield of wheat Triticum aestivum plants and the weed plants that used as test plants were four endemic weed species wild oat Avena fatua, canary grass Phalaris minor, syrian cephalaria Cephalaria syriaca, and cow cockle Vaccaria pyramidata. The study consists of five treatments; foliar application of wheat straw aqueous extract; foliar application of grass weeds herbicide clodinafop-propargyl (Topik); foliar application of broad leaf herbicide tribenuron-methyl (Granstar); zero control (no weed control) and zero weed plots treatments. The study was conducted for growing season of 2010- 
The effect of spraying of wheat straw extracts on controlling some weed species.

2011 in the fields of the agricultural research center of Erbil province. Wheat seeds were sown at 27/ 11/2010 with sowing rate of $100 \mathrm{~kg} /$ Hectare, while weed plants were sown at rate of 10 seeds of each studied species per one meter field, then after germination seedlings were thinned to get only 3 weed plant species from each tested weeds in one meter square land ( Ali, 2001). Fertilizers were used as DAP (Diammonium phosphate) with the rate of $100 \mathrm{~kg} /$ Hectare with sowing process and followed by adding Urea fertilizer after 60 days from sowing with the rate of $80 \mathrm{~kg} /$ Hectare, while herbicide application was conducted 29/1/2010 by using knap-sprayer for the two tested herbicides with wheat straw aqueous extracts that was prepared by collecting fresh wheat straw at harvest time form research agricultural fields then $1000 \mathrm{gm}$ was soaked in 10 liters of distilled water for 24 hours then it was filtered and keprt in deep freeze $-28 \mathrm{C}^{\circ}$ till use ( Iqbal et al., 2009). Two herbicides were used clodinafop-propargyl (Topik) which is a grass weed herbicide and a broad leaf herbicide tribenuron-methyl (Granstar) the rate of these two used herbicide was as it indicated in the label of the herbicide. Spraying was conducted at 3/3/2011 by knapsack sprayer after calibration process to be sure of using the right amount of herbicide diluted solution, liquid ( Yasin et al., 2010). After 48 hours from spraying wheat plants chlorophyll a, $\mathrm{b}$, and total chlorophylls were estimated by using ethanol $100 \%$ as a solvent. The leaf blades were cut into small pieces with sterilized scissors and $0.250 \mathrm{gm}$ was folded in a $25 \mathrm{ml}$ dark bottle with $15 \mathrm{ml}$ ethanol caped and stored in a dark place for 24 hours. The dissolved materials including chlorophylls were decanted into another dark bottle, while the bottles, containing the remaining leaf pieces were rinsed twice with $15 \mathrm{ml}$ of $100 \%$ ethanol and again incubated for 24 hours each time. The rinsing solutions were collected in the original dark bottle and broad to $45 \mathrm{ml}$ with $100 \%$ ethanol. The absorbance of chlorophyll extracts were measured spectrophotometrically at 665 and $649 \mathrm{~nm}$. Then the quantities of chlorophylls were evaluated according to the following equations (Knudson et al., 1977).

$\mu \mathrm{g} \mathrm{Chl} \mathrm{a/ml} \mathrm{solution}=(13.70)\left(\mathrm{A}_{665 \mathrm{~nm}}\right)-(5.76)\left(\mathrm{A}_{649 \mathrm{~nm}}\right) \ldots \ldots$

$\mu \mathrm{g} \mathrm{Chl} \mathrm{b/ml} \mathrm{solution}=(25.80)\left(\mathrm{A}_{649 \mathrm{~nm}}\right)-(7.60)\left(\mathrm{A}_{665 \mathrm{~nm}}\right) \ldots \ldots \ldots . . .(2)$

Chlorophyll concentration was expressed as $\mu \mathrm{g} \mathrm{Chl} \mathrm{/} \mathrm{mg}$ dry weight, which obtained from separate leaf samples. Finally, plants were harvested and wheat yield and 1000 seeds weight was recorded, while yield loss were estimated according to the equation below

yield loss $\%=\frac{w_{0}-W_{s}}{w_{0}} \times 100$

Where $\mathrm{W}_{0}$ is the yield in zero weed plots and $\mathrm{W}_{\mathrm{S}}$ is the yield in studied plots, which include all other investigated factors (Canner et al., 2002) and (Baghstani et al., 2006). Statistical analyses were applied according to SPSS 16 program and Duncan method was used for comparing means of treatments.

\section{Results and Discussion}

Results of the recorded data (table-1) indicated significant differences between all treatments. Data of height of wheat plants was at lowest level wheat plants were treated with Granstar herbicide while the tallest wheat plants were found in treatments that treated with wheat straw extracts, these data results indicated that wheat plants did not affected by its own straw aqueous extracts( Shahid et al., 2006). While when we studied 1000 kernels weight the highest record was found with the use of Topic herbicides meanwhile lowest record was shown when wheat plants were treated with its own aqueous straw extracts, which indicates the severity of competition between grassy weeds with wheat in plots that grassy weeds were eliminated in early stages of commencement of competition by using grass weeds herbicides in this particular study Topic ${ }^{\circ}$ (Ali and Aziz 2002). Yield of the field was estimated according to kilogram per hectare area and the highest value was indicated in zero weed treatments where early and continues hand weeding was persuaded for eliminating the competition effect between the crop and weed plants on the other hand when there wasn't any methods used for weed control the yield of wheat plants was at lowest levels, these results indicated the competition importance in the semi-arid environment which the study was conducted, in such away the using of narrow leaf herbicide causes only 3.60 loss of yield comparing with zero weed plots (figure-1), mean while using broad leaf weed herbicides caused about 22.12 yield loss which, indicates the different ecological niche between broad leaf weeds and wheat plants because by using Granstar® only broad leaf weeds will be killed and grassy or narrow leaf weeds will survive and compete for growth needs with wheat plants, although it is obvious that using wheat aqueous extracts as spray liquid caused yield loss about $31.96 \%$ which may indicate the allelopathic potential of the used extract on wheat plants ( Steinsiek et al., 1982) and (Nakano et al ., 2006). Chlorophyll content for wheat plants that was estimated after 48 hours from spraying process indicated significant differences for $\mathrm{Chl}$ a, $\mathrm{b}$ and total chlorophyll in such manner that it is obvious that using Topic ${ }^{\circledR}$ herbicide and wheat straw extracts caused reduction of all studied data of chlorophyll content comparing to zero weed plants chlorophyll content as shown in (figure-2), these results indicate that all spraying processes caused lowering the levels of chlorophyll a, $\mathrm{b}$, and total where spraying of Topic ${ }^{\circledR}$ caused lowering all recorded data to $68.21,66.11$ and $67.50 \%$ respectively comparing to treatments of no weed plants (figure- 3 ), chlorophyll content indicates the importance of the main photosynthetic pigment content (Heldt. 2005). Weed plants height indicated that wheat straw 
aqueous extracts caused reduction in weed plant height comparing to pure weed stand plots where only weed plants were sown (figure-4), the reason for this phenomenon may be due to the reality that wheat plants straw aqueous extracts may contain allelopathic compounds that affect the growth of weed plants ( Opoku et al., 1997)..

\section{Conclusion}

This study indicates that wheat straw aqueous extracts which caused reducing chlorophyll content of wheat plants besides reducing weed plants height.

\section{Acknowledgements}

We would like to thank (Erbil research center-Kurdistan region-Iraq) for their assistance and help during the implementation of these experiments.

\section{References}

[1] Ismail, B. K. (2006). Effect of water stress on growth, yield, and quality characteristics of eight bread wheat cultivars. MSc. Thesis. College of Science .University of Salahadin. Iraq.

[2] Marof, S. M. (2007). Competititive Interference Between Triticale x Triticosecale rimpaui Wittmac and Wheat Triticum spp. L. under two different environmental conditions. $\mathrm{Ph}$ D. Dissertation. College of Agriculture .University of Salahadin

[3] Al-ali, Aziz. (1980). Guide of agricultural pest control. Agricultural ministry. Institute of plant protection.

[4] Hassawy, G. S., S. A. Tammimi., H. Al-izzi.(1968). Weeds in Iraq. Technical bulletin. Iraq.

[5] Robson, T. O., P. J. Americanos., and B. E. Abu-irmaileh. (1991). Major weeds of the near east. FAO plant protection and production paper.

[6] Gooding, Mike. J., W. Paul. Davies. (1997). Wheat production and utilization system, quality and environment. CBA International. Cambridge. UK.

[7] Labrada, R., J. C. Caseley., and C. Parker. (1994). Weed management for developing Countries. FAO plant protection and production paper.

[8] Macias, F. A., J. C. G. Galindo., D. Castellano., and R. F. Velasco. (1999). Sesquiterpene lactones with potential use as natural herbicide models (1): trans,trans-Germaacranolides. Journal of Agricultural and Food Chemistry. 47: 4407- 4414.

[9] Macias, A. F., D. Castellano, and J. M. G. Molinillo. (2000). Search for a Standard Phytotoxic Bioassay for Allelochemicals. Journal of Agricultural and Food Chemistry. 48: 2512-2521.

[10] Bhatti, M. Q., Z. A. Cheema., and T. Mahmood. (2000). Efficacy of Sorgaab as Natural Weed Inhibitor in Raya. Pakistan Journal of Biological Sciences. 3(7): 1128-1130.

[11] Birkett, M. A., K. Chamberlain., A. M. Hooper., and J. A. Pickett. (2001). Does allelopathy offer real promise for practical weed management and for explaining rhizosphere interactions involving higher plants?. Plant and Soil. 232: 31-39.

[12] Cheema, Z. A., B. Ali., and A. Khaliq. (2005). Determining suitable combination of sorgaab and pendimethalin for weed control in cotton (Gossypium hirsutum). International Journal of Agriculture \& Biology. 7(6): 889- 891.

[13] Ali, K. A. (2010). Utilizing the Allelopathic Potential of Cephalaria syriaca for Controlling Some Endemic Weed Species. PhD. Thesis in Biology. College of Science. University of Salahaddin. Iraq.

[14] Ali, K. A. 2001. Some Ecological studies on Interference between soft wheat (Triticum aestivum) and Syrian Cephalaria (Cephalaria syriaca).M.Sc. Thesis in Biology. College of Education. University of Salahaddin. Iraq.

[15] Iqbal, Javaid., Z. A. Cheema., and M. Naeem. Mushtaq. (2009). Allelopathic crop water extracts reduce the herbicide dose for weed control in cotton (Gossypium hirsutum). International Journal of Agriculture \& Biology. 11(4): $360-366$.

[16] Yasin. M., A. Tanveer., Z. Iqbal., and A. Ali. (2010). Effect of Herbicides on Narrow Leaved Weeds and Yield of Wheat (Triticum aestivum L.). World Academy of Science, Engineering and Technology .68: 1280-1282.

[17] Knudson, L. L., T. W. Tibbitts., and G. E. Edwards. (1977). Measurement of Ozone Injury by Determination of Leaf Chlorophyll Concentration. Plant Physiology. 60; 606-608.

[18] Baghestani, M. A., E. Zand., and S. Soufizadeh.(2006). Iranian Winter Whea's (Triticum aestivum L.) Interference with Weeds: I. Grain Yiled and Competitive Index. Pakistan Journal of Weed Science Research. 12(3): 119-129.

[19] Canner, S. R., L. J. Wiles., and G. S. McMaster. (2002). Weed reproduction model parameters may be estimated from crop yield loss data. Weed Science, 50:763-772.

[20] Shahid, M., B. Ahmad., R. A. Khattak., and M. Arif. (2007). Integration of Herbicides with Aqueous Allelopathic Extracts for Weed Control in Wheat. African Crop science Conference Proceedings Vol.8: 209- 212.

[21] Ali, K. A. and F. H. Aziz. (2002). Studying the effect of root and shoot extracts of syrian cephalaria (Cephalaria syriaca) extract on wheat seeds (Triticum aestivum) germination properties. (Zanco) journal of pure and applied science.(2002) Vol 14. No(2): 15-24.

[22] Steinsiek, J. W., L. R. Oliver., and F. C. Collins. (1982). Allelopathic Potential of Wheat (Triticum aestivum) Straw on Selected Weed Species. Weed Science. Vol.30: 495-497.

[23] Nakano, H., S. Morita., H. Shigemori., and K. Hasegawa. (2006). Plant Growth Inhibitory Compounds from Aqueous Leacheate of Wheat Straw. Plant Growth Regulation. 48: 215-219.

[24] Heldt, H. Walter. (2005). Plant Biochemistry, 3rd Edition. Elsevier Academic Press. USA.

[25] Opoku, G., T. J. Vyn., and R. P. Vorony. (1997). Wheat Straw Placement effects on Total Phenolic Compounds in Soil and Corn seedling Growth. Canadian Journal of Plant Science.77 (3): 301-305. 
The effect of spraying of wheat straw extracts on controlling some weed species.

Table 1: Effect of Spraying of wheat straw Aqueous extracts on some recorded data

\begin{tabular}{|c|c|c|c|c|}
\hline treatment & Height & $\begin{array}{c}1000 \text { seed weight } \\
\text { (grams) }\end{array}$ & Kg. hectar ${ }^{-1}$ & reduction $(\mathrm{Kg})$ \\
\hline $\begin{array}{l}\text { wheat straw } \\
\text { extract }\end{array}$ & $105.33 \mathrm{a}$ & $39.85 \mathrm{c}$ & 2013.33 c & $946.67 \mathrm{~b}$ \\
\hline Topic $®$ & $99.00 \mathrm{~b}$ & $43.24 \mathrm{a}$ & 2853.33 a & $106.67 \mathrm{~d}$ \\
\hline Granstar $®$ & $87.67 \mathrm{c}$ & $42.38 \mathrm{ab}$ & $2306.67 \mathrm{~b}$ & $653.33 \mathrm{c}$ \\
\hline Zero Control & $102.67 \mathrm{ab}$ & 41.12 bc & $1776.67 \mathrm{~d}$ & $1183.33 \mathrm{a}$ \\
\hline Zero (No) Weed & $105.00 \mathrm{a}$ & $40.48 \mathrm{c}$ & $2960.00 \mathrm{a}$ & $0.00 \mathrm{~d}$ \\
\hline
\end{tabular}

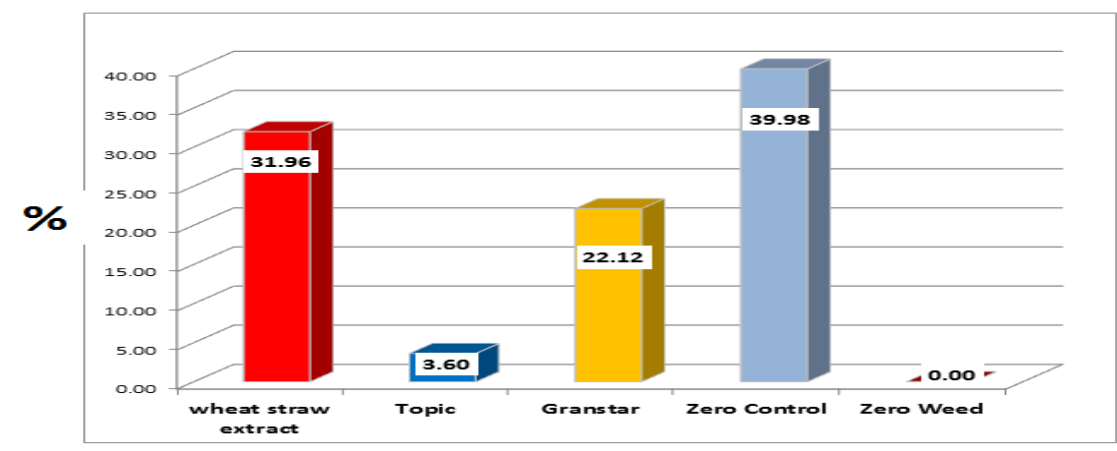

Figure 1: Reduction Percentage Comparing to Zero Weed Treatments

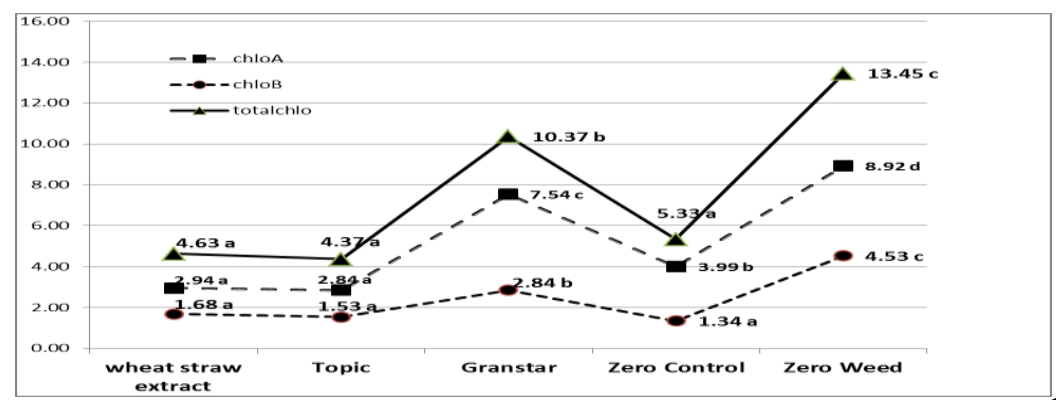

Figure 2: Chlorophyll a, b and total levels after 48 hours from spraying as $\mu \mathrm{g}$. $\mathrm{mg}^{-1}$ dry weight.

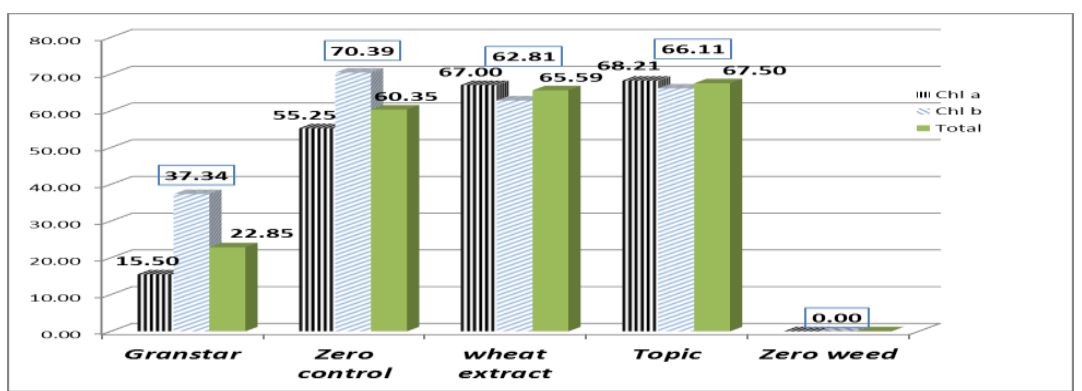

Figure 3: Reduction Levels of Chlorophyll Percentage comparing to Zero Weed treatments

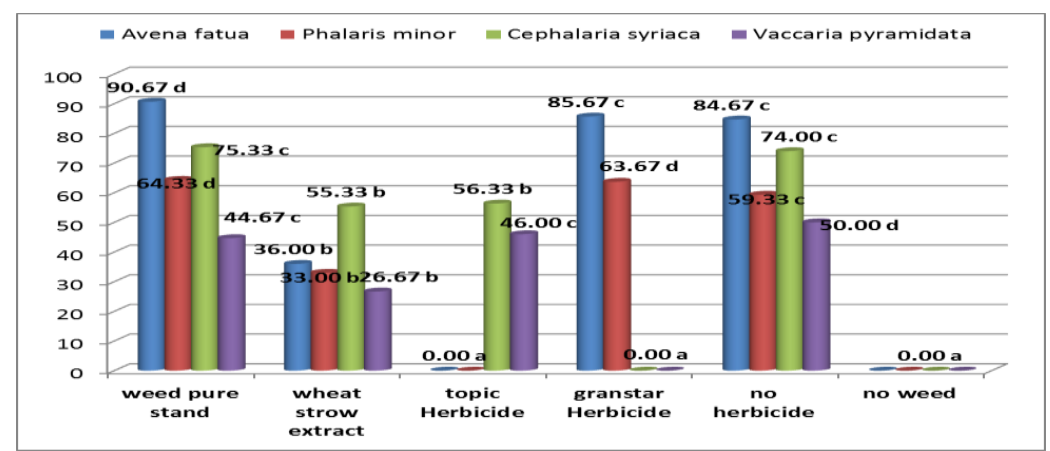

Figure 4: Recorded Weed Plants Height in centimeters 